\title{
Disclosure of Islamic Social Reporting A Comparative Study of Indonesia and Malaysia
}

\author{
Erik Nugraha ${ }^{1}$, Tri Anita Noviantini' ${ }^{2}$, Audita Setiawan ${ }^{3}$ \\ Program Studi Akuntansi, Fakultas Ekonomi, Universitas Sangga Buana ${ }^{1}$ \\ Program Studi Akuntansi, Fakultas Ekonomi, Universitas Sangga Buana ${ }^{2}$ \\ Program Studi Akuntansi, Fakultas Ekonomi, Universitas Sangga Buana ${ }^{3}$
}

\begin{abstract}
This study aims to describe and determine the differences in the disclosure of Islamic Social Reporting (ISR) in Islamic Banks in Indonesia and Malaysia. Islamic Social Reporting (ISR) is an extension of the reporting standards of social performance as a reflection of the company's role in a spiritual perspective. The method used in the research is descriptive comparative method using cross-sectional data types. The population in this study is Islamic Banks in Indonesia, which are as many as 13 banks and in Malaysia which are as many as 15 banks, the sampling technique used in this study uses census sampling techniques. The data analysis technique used is the Independent ttest. Based on the results of the study there are not differences in the disclosure of Islamic Social Reporting (ISR) in Islamic Banks in Indonesia and Malaysia, but the level of disclosure of Islamic Social Reporting (ISR) in Islamic Banks in Malaysia is better than Islamic Banks in Indonesia.
\end{abstract}

Keyword. islamic social reporting

Article History. Received January, 2019. Revised March, 2019. Accepted June, 2019

Corresponding Author. erik.nugraha@usbypkp.ac.id

How to cite article. Wardani, M. K., \& Sari, D. D. (2019). Disclosure of Islamic Social Reporting in Sharia Banks: Case of Indonesia and Malaysia. The International Journal of Business Review (The Jobs Review), 1(2), 39-46. https://doi.org/https://doi.org/10.17509/tjr.v2i1.20335

\section{INTRODUCTION}

Along with public awareness about nature care and social welfare in the surrounding environment, information related to this aspect is also considered when a company publishes its annual report, especially for companies going public. This aspect is known as Corporate Social Responsibility. In Indonesia, awareness about CSR can be seen from the increasing number of companies that disclose CSR issues in annual financial reports. Including the holding of the Indonesian Sustainability Reporting Award (ISRA) which will give the company added value regarding its success in carrying out CSR activities that are environmentally friendly. The sharia banking sector also does not want to miss following this regulation especially the government also accommodates regulations regarding the disclosure of CSR practices specifically for sharia financial institutions in Law No. 21 of 2008 concerning Sharia Banking which mentions the social function of sharia banks which includes the collection and distribution of funds the community.

The development of Islamic banking and financial institutions in Indonesia began with the establishment of Bank Muamalat Indonesia (BMI) in 1991 and operated effectively in 1992. Indonesia is somewhat late in developing Islamic financial institutions compared to neighboring Malaysia which had established the Islamic Bank Malaysia Berhad (BIMB ) since 1983. History shows that sharia banking in Malaysia has developed ahead of other countries in the Southeast Asian region. Governments in Muslim-majority countries such as Indonesia and Malaysia as well as international regulatory institutions such as the Accounting and Auditing Organization for Islamic Financial Institutions (AAOIFI) continuously voiced and sought the development and adoption of reporting formats such as 
Corporate Social Responsibility (CSR) reports to be formulated for Islamic financial institutions. AAOIFI is known as an international sharia accounting standard organization that was founded in 1991 and based in Bahrain.

The concept of CSR in Islam uses the philosophy of the Qur'an and the Hadith. In Islamic financial institutions called Islamic Social Reporting (ISR). ISR is a measure of the implementation of social performance that contains a compilation of CSR standard items set by AAOIFI which are then further developed by researchers regarding CSR items that should be disclosed in an Islamic entity. In accordance with the components in the ISR for Islamic entities because they reveal things related to Islamic principles such as transactions that are free from usury, speculation and gharar, as well as disclosing zakat, sharia compliance status and social aspects such as sodaqoh, waqof, qordul hasan, until the disclosure of worship in the corporate environment.

Based on data from the Global Islamic Finance Report (GIFR) in 2018 in the Islamic Finance Country Index (IFCI) report placing Malaysia at the top of the list of countries that lead the global sharia industry with a score of 81.01 followed by Iran, Saudi Arabia, the United Arab Emirates, and Kuwait respectively ranked second, third, fourth and fifth. While Indonesia managed to move one position up from the previous year to win the 6th position with a score of 24.13. As the country with the largest Muslim population, GIFR said that Indonesia is ready to become a global player in Islamic finance. Indonesia's position in the global Islamic financial industry market also shows significant development and now Indonesia is juxtaposed with the GCC (Gulf Cooperation Council) and Malaysia countries which in fact are the largest Muslim countries such as the UAE, Kuwait, Bahrain, Oman and Qatar. These countries are considered to have great potential in the development of Islamic finance globally.

Islam governs human life is not only related to human relations with God, but also regulates the relationship between humans. Therefore, the relationship with God and the relationship between humans can not be separated in this life. During the CSR measurements used in companies that are based on the Global Initiative Initiative Index (GRI), however the measurement and disclosure is certainly not appropriate for Islamic entities that must comply with Islamic law and must disclose information that business operations are in accordance with Islamic law (Haniffa, 2002). In his research (Othman, Thani, \& Ghani, 2009) developed a disclosure index relevant to Islamic entities called the Islamic Social Reporting Index (ISR). The ISR was first put forward by (Haniffa, 2002)and later developed more widely by (Othman et al., 2009) in Malaysia. There are limitations to conventional social reporting which only prioritizes a conceptual framework based on regulations, whereas Islamic Social Reporting (ISR) not only helps make decisions for Muslims but also helps companies fulfill obligations towards God and society (Haniffa, 2002).

Several studies related to Islamic Social Reporting have been widely available in Indonesia, especially in the banking industry. Research conducted by (Asriati, Ulfah, \& Setyorini, 2016) who took samples of Sharia Commercial Banks in Indonesia and Malaysia in 2012-2014 showed that the social performance of Islamic banks in Indonesia has increased $8.5 \%$ annually while for Islamic banks in Malaysia each year has increased by $9 \%$. The results of the study (Amran et al., 2017)show that the social disclosure of Islamic banks in general has grown both in Indonesia and Malaysia. Based on the previous research, the purpose of this research is to find out and describe whether there are differences in Islamic Social Reporting disclosures in Islamic Commercial Banks in Indonesia and Malaysia.

\section{METHOD}

40 | The International Journal of Business Review (The Jobs Review) | Vol.2 | No.1 | 2019 
The research method is a scientific way to obtain data with specific goals and uses (Sugiyono, 2012). The research method used in this study when viewed from the level of exploration is descriptive and comparative methods. Descriptive method is a method used to describe or analyze a research result but is not used to make broader conclusions. The comparative method is research that compares the state of one or more variables in two or more different samples, or two different times.

This study uses cross-sectional data types. According to Chandrarin (2017) crosssectional data is a type of data whose value is taken at a certain time (one shoot time) within the limits corresponding to certain measurement attributes. Cross-sectional data is determined based on variations of data taken at that particular moment (ignoring the time period). The source of the data used is a secondary data source, according to Chandrarin (2017) secondary data, namely data from parties or institutions that have used or published it. Because the data can be ascertained for its use and publication, there is no need for researchers to test its validity and reliability. If there is an error or inaccuracy then it is not the responsibility of the researcher (responsibility rests with the party or institution that uses and publishes it).

Chandrarin (2017) defines the population is a collection of elements that have certain characteristics that can be used to make conclusions. The population in this study is Sharia Commercial Banks in Indonesia, namely 13 banks (according to the FSA data) and in Malaysia, there are 15 banks (according to the State Bank of Malaysia) in 2017. The sampling technique used is census sampling technique, census is a technique taking overall from population members.

The variable used in this study is sharia banking social responsibility which is seen through the level of Islamic Social Reporting disclosure. The level of Islamic Social Reporting disclosure in this study was measured using the ISR index which contains a compilation of disclosure items. The ISR index is divided into six main categories namely Finance and Investment themes, Product and Service themes, Employees themes, Society themes, Environment themes, and Corporate Governance themes. According to Ghozali (2016) in (Sarah, Nugraha, \& Nugroho, 2018) a different t-test is used to determine whether two samples that are not paired with each other or have different mean values. Non-pairing can mean that research is conducted for two different sample subjects. In this study the Independent T-test is used to identify differences in earnings management in Islamic Commercial Banks in Indonesia and in Malaysia. Prior to the Independent T-test, a data normality test was performed with the Shapiro-Wilk test. If the data is normally distributed, a homogeneity or variance test is performed with the F-Test or Levene's Test. In this study, the two data groups have the same variant so that the Independent T-test test value is read on the Equal variance. Data is stated to have the same variance (equal variance) if FCalculate <F-Table, and vice versa, data variants are declared unequal variance if $\mathrm{F}$ Calculate> F-Table. The shape of the variants of the two groups of data will affect the standard error value which will eventually differentiate the test formula. Independent T-test for the same variance (equal variance) using the Polled Variance manual formula. Hypothesis testing is done by using the Independent T-test at a 95\% confidence level with an error rate of analysis $(\alpha) 5 \%$. Criteria for acceptance or rejection of hypotheses will be based on p-values. Decisions based on probability as follows.

1. If the p-value $>0.05$ then the hypothesis is rejected (not significant)

2 . If $\mathrm{p}$-value $<0.05$, the hypothesis is accepted (significant)

\section{RESULTS AND DISCUSSION}

This study was measured by a score that refers to the ISR index. ISR values were obtained from the results of content analysis of all study samples. Following are the results

41 | The International Journal of Business Review (The Jobs Review) | Vol.2 | No.1 | 2019 
of a descriptive analysis using content analysis at Islamic Commercial Banks in Indonesia and in Malaysia. The ISR index is as follows:

Table 1. Indeks Islamic Sosial Reporting

\begin{tabular}{|c|c|c|c|c|}
\hline Country & $\mathrm{N}$ & Minimum & Maximum & Mean \\
\hline Indonesia & 13 & 0,302 & 0.721 & 0,578 \\
\hline $\begin{array}{c}\text { Malaysia } \\
\text { Total }\end{array}$ & $\begin{array}{l}15 \\
28\end{array}$ & 0.233 & 0.814 & 0,600 \\
\hline
\end{tabular}

Based on table 1 it can be seen that the minimum value of ISR index disclosure at banks in Indonesia is 0.302 and the maximum value is 0.721 with an average disclosure value of 0.578 . While the minimum ISR index disclosure in Malaysia is 0.233 and the maximum value is 0.814 with an average disclosure of 0.600. It can be seen that the Sharia Commercial Bank that has the least disclosure value is in the country of Malaysia, as well as the Sharia Commercial Bank that has the most disclosure value also in the country of Malaysia. And the difference in maximum value of Islamic Commercial Banks in Indonesia and Malaysia is 0.093 or only $9.3 \%$. The results of the content analysis of each Sharia Commercial Bank both in Indonesia and in Malaysia can be seen in table 2 and 3 as follows:

Table 2. Indeks Islamic Sosial Reporting Indonesian Islamic Banking in 2017

\begin{tabular}{clc}
\hline No & \multicolumn{1}{c}{ Bank in Indonesia } & Nilai (\%) \\
\hline 1 & PT. Bank Aceh Syariah & 0,628 \\
2 & PT. Bank Muamalat Indonesia & 0,651 \\
3 & PT. Bank Victoria Syariah & 0,302 \\
4 & PT. Bank BRI Syariah & 0,698 \\
5 & PT. Bank Jabar Banten Syariah & 0,512 \\
6 & PT. Bank BNI Syariah & 0,721 \\
7 & PT. Bank Syariah Mandiri & 0,674 \\
8 & PT. Bank Mega Syariah & 0,605 \\
9 & PT. Bank Panin Dubai Syariah & 0,605 \\
10 & PT. Bank Syariah Bukopin & 0,628 \\
11 & PT. BCA Syariah & 0,581 \\
12 & PT. BTPN Syariah & 0,512 \\
13 & PT. Maybank Syariah Indonesia & 0,395 \\
\hline
\end{tabular}

Table 3. Indeks Islamic Sosial Reporting Malaysian Islamic Banking in 2017

\begin{tabular}{clc}
\hline No & \multicolumn{1}{c}{ Bank in Malaysia } & Nilai (\%) \\
\hline 1 & Affin Islamic Bank Berhad & 0,535 \\
2 & Al Rajhi Banking \& Investment Corporation (Malaysia) & 0,651 \\
& Berhad & \\
3 & Alliance Islamic Bank Berhad & 0,767 \\
4 & AmBank Islamic Berhad & 0,767 \\
5 & Bank Islam Malaysia Berhad & 0,651 \\
6 & Bank Muamalat Malaysia Berhad & 0,605 \\
7 & CIMB Islamic Bank Berhad & 0,698
\end{tabular}

42 | The International Journal of Business Review (The Jobs Review) | Vol.2 | No.1 | 2019 


\begin{tabular}{clc}
\hline No & \multicolumn{1}{c}{ Bank in Malaysia } & Nilai (\%) \\
\hline 8 & HSBC Amanah Malaysia Berhad & 0,349 \\
9 & Hong Leong Islamic Bank Berhad & 0,512 \\
10 & Kuwait Finance House (Malaysia) Berhad & 0,581 \\
11 & MBSB Bank Berhad & 0,791 \\
12 & Maybank Islamic Berhad & 0,744 \\
13 & Public Islamic Bank Berhad & 0,814 \\
14 & RHB Islamic Bank Berhad & 0,302 \\
15 & Standard Chartered Saadiq Berhad & 0,233 \\
\hline
\end{tabular}

Based on table 2 it can be seen that the lowest Islamic Social Reporting (ISR) index value for Sharia Commercial Banks in Indonesia in 2017 has a minimum value of 0.302 owned by Victoria Syariah Bank. While the highest ISR index value in Islamic Commercial Banks in Indonesia in 2017 has a maximum value of 0.721 owned by BNI Syariah Bank.

Sharia Commercial Banks in Malaysia in 2017 have a minimum ISR index value of 0.233 which is owned by Standard Chartered Saadiq Berhad (Bank SC). While the highest ISR index of Islamic Commercial Banks in Malaysia in 2017 has a maximum value of 0.814 owned by Public Islamic Bank Berhad.

Data analysis techniques in this study used the Independent T-Test, the analysis was carried out in order to test the hypothesis. Before testing hypotheses, data normality tests are first performed as a condition of using parametric statistics. In this study, the data normality test uses the Shapiro-Wilk test. Decisions based on significance level as follows:

Following are the results of the data normality test with the Shapiro-Wilk test:

Table 4. Shapiro-Wilk Normality Test Results

\begin{tabular}{ccccc}
\hline \multirow{2}{*}{ Country } & & \multicolumn{3}{c}{ Shapiro-Wilk } \\
\cline { 3 - 5 } & & Statistic & Df & Sig. \\
\hline \multirow{2}{*}{ Islamic Social Reporting } & Indonesia &, 893 & 13 &, 108 \\
& Malaysia &, 904 & 15 &, 111 \\
\hline
\end{tabular}

Based on table 4 it can be seen that the ISR index value data at Islamic Commercial Banks in Indonesia has a significance level of 0.108 which is greater than 0.05 and the ISR index value data at Islamic Commercial Banks in Malaysia has a significance level of 0.111 which is greater than 0.05 . It can be concluded that the ISR index value data on Islamic Commercial Banks in Indonesia and Malaysia are normally distributed. The next step is to do a homogeneity or variance test using the Levene Test. Decisions based on significance level as follows:

Table 5. Levene Homogeneity Test Results

\begin{tabular}{llrrrr}
\multicolumn{2}{c}{ Test of Homogeneity of Variance } & & & \\
\hline & & Levene & & & \\
& & Statistic & df1 & df2 & Sig. \\
\hline Islamic Social & Based on Mean & 2,380 & 1 & 26 &, 135 \\
Reporting & Based on Median & 1,923 & 1 & 26 &, 177 \\
& Based on Median and with adjusted df & 1,923 & 1 & 23,563 &, 179 \\
& Based on trimmed mean & 2,337 & 1 & 26 &, 138 \\
\hline
\end{tabular}

Based on table 4 it can be seen that the ISR index value data based on an average has a significance level of 0.135 which is greater than 0.05 which means that the data has the same variance (equal variances). Hypothesis testing using parametric statistics Independent 
t-test can be done because the conditions for using parametric statistics have been met such as, the data must be normally distributed and the data have the same variant. The results of testing the statistical hypothesis in this study are as follows:

Table 5. Independent t-test Hypothesis Test Results

\begin{tabular}{|c|c|c|c|c|c|c|c|c|}
\hline & & \multicolumn{7}{|c|}{ t-test for Equality of Means } \\
\hline & & \multirow[b]{2}{*}{$\mathrm{T}$} & \multirow[b]{2}{*}{$d f$} & \multirow{2}{*}{$\begin{array}{l}\text { Sig. } \\
(2- \\
\text { tailed) }\end{array}$} & \multirow{2}{*}{$\begin{array}{c}\text { Mean } \\
\text { Difference }\end{array}$} & \multirow{2}{*}{$\begin{array}{l}\text { Std. Error } \\
\text { Difference }\end{array}$} & \multicolumn{2}{|c|}{$\begin{array}{l}95 \% \text { Confidence Interval } \\
\text { of the Difference }\end{array}$} \\
\hline & & & & & & & Lower & Upper \\
\hline \multirow{2}{*}{$\begin{array}{l}\text { Islamic } \\
\text { Social } \\
\text { Reporting }\end{array}$} & $\begin{array}{l}\text { Equal } \\
\text { variances }\end{array}$ &,- 371 & 26 &, 714 &,- 022154 & ,059761 &,- 144995 & ,100688 \\
\hline & $\begin{array}{l}\text { assumed } \\
\text { Equal } \\
\text { variances } \\
\text { not } \\
\text { assumed }\end{array}$ &,- 382 & 24,350 & ,706 &,- 022154 & ,058023 &,- 141816 & ,097508 \\
\hline
\end{tabular}

Based on testing data have the same variance (equal variances) with a significance level of $y$ is 0.714 which means greater than 0.05 , Ho is accepted, which means there is no difference in the disclosure of Islamic Social Reporting (ISR) at Islamic Commercial Banks in Indonesia and Malaysia.

This study uses the Independent t-test to determine whether there are differences in the disclosure of Islamic Social Reporting (ISR) at Islamic Commercial Banks in Indonesia and Malaysia through the content analysis method. The items disclosed are compared to items that should have been disclosed so that it results in a percentage disclosure value from each sample of a Sharia Commercial Bank.

Content analysis shows that the level of ISR disclosure of Islamic banks in Malaysia is better than Islamic banks in Indonesia. With Malaysia an average disclosure value of $60 \%$, while Indonesia obtained an average disclosure value of $57.8 \%$ which means only a difference of $2.2 \%$. It can be concluded that the average number of ISR disclosures obtained by Islamic banks in Malaysia is $60 \%$ of the total 43 disclosure items, which means that on average Islamic banks in Malaysia have revealed ISR of 26 items. Whereas Islamic banks in Indonesia obtain an average amount of disclosure value of $57.8 \%$ of the total 43 items that should be, which means that on average Islamic banks in Indonesia have revealed ISR of 24 items.

Based on table 2 it can be seen that Victoria Syariah Bank has the lowest disclosure value of $30.2 \%$ compared to 12 other Islamic banks in Indonesia in 2017. Standard Chartered Saadiq Berhad has the lowest disclosure value compared to 14 other Islamic banks in Malaysia, which is $23,3 \%$ only. Bank BNI Syariah has the highest disclosure value compared to 12 other Indonesian Islamic banks, which is $72.1 \%$. While Public Islamic Berhad has a disclosure value of $81.4 \%$, which means the highest disclosure compared to 14 other Islamic banks in Malaysia. Comparison of disclosure of sharia bank social responsibility in Indonesia and Malaysia when viewed from per the ISR Index theme shows that in the two countries the disclosure theme that has the highest score is the theme of Corporate Governance this shows that almost all Islamic banks in Indonesia and Malaysia try to improve corporate governance and disclose it in an annual report. In this case, it can be seen that Islamic banks in Indonesia are able to offset the disclosure value of Islamic banks in Malaysia, although overall Islamic banks in Malaysia are still superior to Islamic banks in Indonesia. 
Meanwhile, if viewed from the ISR index theme, namely for Islamic banks in Indonesia, the theme of the lowest disclosure is the theme Environment, because the theme of the environment in the ISR index is more directly related to the preservation of natural resources, while the operational activities of Islamic banking are not directly related to the utilization natural resources so that this theme is still unfamiliar in the annual report of Islamic banks in Indonesia. And the theme that has the lowest disclosure value for Islamic banks in Malaysia is the theme of Finance and Investment, in Malaysia there are a number of Islamic banks that still have not revealed the Riba sub-item and the Company Value Added Report. For this sub item, it does not mean that banks in Malaysia do not carry out operational activities according to sharia principles, only that there are a number of banks that do not include them in the published annual report.

The results of testing the hypothesis in this study that there is no difference in the disclosure of Islamic Social Reporting (ISR) at Islamic Commercial Banks in Indonesia and Malaysia. This is in accordance with the concept of Legitimacy theory which states that the company's operating system must be oriented to the alignment of the community, government, individuals and community groups. So that the social performance and disclosure of company information is used to legitimize the company's activities in the eyes of the public for the company's sustainability. No significant differences could be found because in this study all samples were taken from the two countries that adhered to the same regulations and were overseen by the same international body even though the overall level of disclosure of ISR of Islamic banks in Malaysia was better than that of Islamic banks in Indonesia. This is consistent with previous research by (Sofyani, Ulum, Syam, \& L., 2012) comparing the social performance of Indonesian and Malaysian Islamic banks in 2009-2010, the results show that Islamic banks in Indonesia continue to improve to improve their social performance from year to year. years in accordance with existing regulations, and from the two countries are still the same, no one has revealed the items in ISR in full 100\%. This study is also consistent with research (Sawitri \& Nandari Yanni Latrini, 2015) which states that there is no Islamic bank in Indonesia that fully discloses its social performance in accordance with the ISR index, each item disclosed is still not reaching $100 \%$. However, this study contradicts the research (Asriati et al., 2016) which states the results of the hypothesis test found that there are significant differences between the level of ISR disclosure of Islamic banks in Indonesia and in Malaysia. This difference can occur due to the taking of different sample years, this study uses a sample of Islamic banks in Indonesia and Malaysia in 20122014 so it is possible that there has been a significant change in the development of the Islamic bank industry in Indonesia which causes in 2017 there is no difference between reporting Islamic banks' social performance in Indonesia and Malaysia referring to the ISR index.

\section{CONCLUSION}

Based on the results of hypothesis testing using the Independent t-test, a significance value of 0.714 is obtained that is greater than 0.05 , so it can be concluded that there is no difference in the disclosure of Islamic Social Reporting (ISR) at Islamic Commercial Banks in Indonesia and Malaysia. The implication of this research is that it is hoped that the implementation of company activities is not only focused on the welfare of the company, but the main purpose of Islamic banks is for the welfare of society and the benefit of the people, from the results of this study it is proven that Indonesia can compete with Malaysia which is also a Muslim-majority country. so it does not rule out the possibility that the Islamic banking industry in Indonesia can outperform the banking industry in Malaysia. 


\section{REFERENCES}

Amran, A., Fauzi, H., Purwanto, Y., Darus, F., Yusoff, H., Zain, M. M., ... Nejati, M. (2017). Social Responsibility Disclosure in Islamic Banks: a Comparative Study of Indonesia and Malaysia. Journal of Financial Reporting and Accounting, 15(1), 99-115. https://doi.org/10.1108/JFRA-01-2015-0016

Asriati, R., Ulfah, P., \& Setyorini, C. T. (2016). Analisis Perbandingan Komponen Islamic Social Reporting ( ISR ) Pada Bank Syariah Antara Negara Indonesia dan Malaysia. Simposium Nasional Akuntansi XIX, (1997), 1-24.

Chandrarin, Grahita. 2017. Metode Riset Akuntansi. Salemba Empat. Jakarta.

Haniffa, R. (2002). Social Reporting Disclosure An Islamic Perspective. Indonesian Management \& Accounting Research. Indonesian Management \& Accounting Research.

Othman, R., Thani, A. M., \& Ghani, E. K. (2009). Determinants of Islamic Social Reporting Among Top Shariah-Approved Companies in Bursa Malaysia. Research Journal of International Studies, 12(May), 4-20.

Sarah, V. A., Nugraha, E., \& Nugroho, L. (2018). Does Earning Management Happen in Islamic Bank? (Indonesia and Malaysia Comparison). International Journal of Commerce and Finance, 4(2), 47-59. Retrieved from http://ijcf.ticaret.edu.tr/index.php/ijcf/article/view/93

Sawitri, A. W., \& Nandari Yanni Latrini, M. (2015). Pengaruh Sikap Skeptis, Independensi, Penerapan Kode Etik, Dan Akuntabilitas Terhadap Kualitas Audit. E-Jurnal Akuntansi, 10(1), 164-181. https://doi.org/ISSN : 2302-8578

Sofyani, H., Ulum, I., Syam, D., \& L., S. W. (2012). Islamic Social Reporting Index Sebagai Model Pengukuran Kinerja Sosial Perbankan Syariah (Studi Komparasi Indonesia Dan Malaysia). Jurnal Dinamika Akuntansi, 4(1). https://doi.org/10.15294/jda.v4i1.1958

Sugiyono. 2012. Metode Penelitian Bisnis. Cetakan Ke-16. Alfabeta. Bandung. 